\title{
Strategic Research, Technological Innovation and Nursing
}

\author{
Maria Helena Palucci Marziale
}

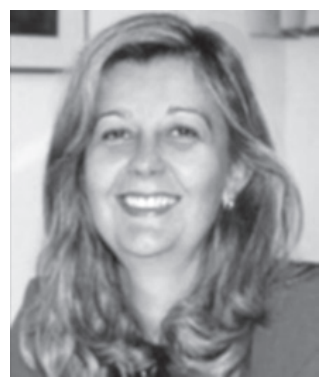

Technological innovation is defined as a process of conceiving or gathering new functionalities or characteristics for a product or production method. In this movement, shifts in quality or productivity that are able to adapt a business or a service to the market reality are explored. It can be classified as product innovation, when introduced into the market, or process innovation, when used in the production process ${ }^{(1)}$. The concept also refers to the introduction of a new product, service or process into the market, based on the available knowledge, whether recent or previously generated. Innovation is the knowledge in action, it is the knowledge widely used in society and productive organizations, whether they are goods or health services ${ }^{(2)}$.

The theme technological innovation and health has increasingly gained ground share in the academy and in public policies in Brazil since the organization, in 1994, of the 1st National Science and Technology in Health Conference ${ }^{(3)}$. Scientific innovation systems benefit the development of the country, as a strong national scientific capacity provides a basis to sustain political decisions and improve people's lives. In our country, the challenges to improve people's lives are vast and diversified, and they cannot be faced without the contribution of scientific knowledge and innovative technologies.

The vaccine that eradicated smallpox, oral re-hydration therapy, which saves the lives of millions of children with diarrhea; the integrated wielding of plagues, which increased rice production and decreased the use of pesticides; the creation of many high return varieties of wheat and rice that transformed food safety in Southern Asia; the water purification techniques that reduced the risk of epidemics after natural disasters; the mobile telephones that improved access to urban and rural markets and helped to strengthen the family bonds are some examples of technologies that exerted considerable influence to improve the life of people. These improvements were achieved through years of experimentation, carried out in collaboration by groups of scientists from different countries and areas of expertis ${ }^{\mathrm{e}(4)}$. Hence, interdisciplinarity and partnerships among research groups are highlighted as a valuable instrument in this process.

The creation of effective innovative global science systems, with the participation of scientists from developing and developed countries, to research the necessities of developing countries, will permit the achievement of the Millennium Development Goals ${ }^{(5-6)}$. Thus, strategic research, with the scientific and technological community's attentive look at health needs and policies, addressing themes that deal with international and national challenges and require resources and multi-institutional bonds, should be developed in all areas of expertise.

Some forecasted challenges are related to climate changes, due to the increasing frequency and severity of climate events, such as droughts, extreme temperatures, floods and tropical storms. The globalization of trade and travelling contributed to the fast movement of new plagues and diseases in agriculture and cattle, leading to more 
frequent outbreaks and threatening agricultural production and trade. The same globalization process is increasing the risks of wide-spread human infectious diseases where new pathogenic agents emerge, associated to a mix of human and animal pathogens. Therefore, the construction of technical capacity to monitor populations and the environment is necessary, capable of detecting shocks, as well as capacities of forecasting and anticipation models, and a range of answers that help communities and nations to prevent, tolerate and recover from disasters. This will contribute to development itself, including the improvement of food safety, human health and management of natural resources. In science, an increase in new platforms is observed, flexible to be easily transformed for the rich and poor's problems, and a revolution in information and communication technologies, expanding our capacity to communicate and participate in global scientific innovation, to involve interested parties and the beneficiaries of this process, besides crossing over the historical boarders of developed and developing countries ${ }^{(4)}$.

In view of this scenario, Nursing has many challenges, such as: training scientists who can work internationally in science innovation. This role should be performed by the teaching systems, undergraduate and graduate programs. Financial institutions should increase financial support for national research. Also, there is the need to help scientists from developing countries to participate in innovation systems through global research with specialists from other nations. These research partnerships should be fairer and enable the development of scientists, supporting their careers in national institutions through long-term research opportunities, publications and creation of research groups.

Specifically in the Nursing area, there is a need to increase the number of high impact and technological innovation research, with a view to the reduction of poverty and the improvement of the community's wellbeing.

\section{References}

1. Ministério de Ciência e Tecnologia. Programa juro zero. Brasília. [citado em 23 mar 2009]. Disponível em: http://www.jurozero. finep.gov.br/jurozero_prod/autenticar

2. Anais da $2^{a}$ Conferência Nacional de Ciência, Tecnologia e Inovação em Saúde; 2004 Jul 25-28; Brasília (DF), Brasil. Brasília (DF): Ministério da Saúde; 2004.

3. Pereira Júlio Cesar Rodrigues, Baltar Valéria Troncoso, Mello Débora Luz de. Sistema Nacional de Inovação em Saúde: relações entre áreas da ciência e setores econômicos. Rev. Saúde Pública [periódico na Internet]. 2004 Fev [citado 2010 Fev 17] ; 38(1): 1-8. Disponível em: http://www.scielo.br/scielo.php?script=sci_arttext\&pid=S0034-89102004000100001\&lng=pt. doi: 10.1590/S003489102004000100001.

4. Conway, Gordon; Waage, Jeff; Delaney, Sara. Science and Innovation for Development. UK Collaborative on Development Sciences (UKCDS), London, January 2010.ISBN: 9781841290829

5. Technology and Innovation.UN. (2009) The Millennium Development Goals Report, 2009, UN, New York.

6. Marziale Maria Helena Palucci, Mendes Isabel Amélia Costa. Poverty and human development: global strategies. Rev. Latino-Am. Enfermagem [periódico na Internet]. 2007 Out [citado 2010 Fev 17] ; 15(spe): 713-720. Disponível em: http://www.scielo.br/scielo. php?script=sci_arttext\&pid=S0104-11692007000700001\&lng=pt. doi: 10.1590/S0104-11692007000700001.

Maria Helena Palucci Marziale is Editor of Latin American Journal of Nursing, Full Professor, Escola de Enfermagem de Ribeirão Preto, Universidade de São Paulo, WHO Collaborating Centre for Nursing Research Development, Ribeirao Preto, SP, Brazil, e-mail: marziale@eerp.usp.br. 